\title{
3 The development of the North American film industry in 2018
}

\author{
Lora Yan Chen
}

\section{The general state of the North American film and television industry}

\section{The new trends in the North American film market}

Founded in 1922, the Motion Picture Association of America (MPA or MPAA) is a non-profitable organization that provides services for the six major film companies in America. Members of MPAA include the six major Hollywood film production and distribution companies:

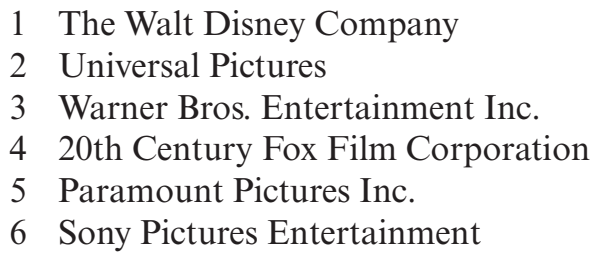

As the representative of the six major studios, the work of MPA mainly includes the following aspects: (1) communicating with the government as well as with other industries and businesses; (2) implementing and promoting the relevant laws and policies governing society; (3) protecting intellectual property rights and stopping the pirating of films; (4) investigating the film and television market and commissioning a market survey report of the film and television industry as well as a report on the relations between the film and television industry and the national economy; and (5) giving film gradings.

Every year, the MPAA supervises and produces the market report of global film box office for its member companies and provides detailed data and information on the North American market.

As shown in Table 3.1, the global box office in 2018 reached US $\$ 41.1$ billion which had increased by 1.5 percent compared to the box office performance of 2017, and by 13 percent compared to the global box office income in 2014 . The major reason for the rapid increase in global box office was the dramatic increase in overseas box office income. Although the overseas box office in 
Table 3.1 Box office and growth rate in North America and international regions, 2014-2018 (US\$100 million)

\begin{tabular}{lccccccc}
\hline Regions & 2014 & 2015 & 2016 & 2017 & 2018 & $\begin{array}{l}\text { Growth } \\
\text { rate 1 (\%) }\end{array}$ & $\begin{array}{l}\text { Growth } \\
\text { rate 2 (\%) }\end{array}$ \\
\hline North America & 104 & 111 & 114 & 111 & 119 & 7 & 14.4 \\
International regions & 260 & 273 & 274 & 294 & 292 & -1 & 12 \\
Total & 364 & 384 & 388 & 405 & 411 & 1.5 & 13 \\
\hline
\end{tabular}

Source: Motion Picture Association of America, see (www.mpaa.org/).

Notes: North America refers to the United States and Canada, international regions refer to other countries except North America; growth rate 1 refers to the growth rate of 2018 relative to 2017, while growth rate 2 refers to the growth rate of 2018 relative to 2014 .

Table 3.2 Box office and growth rate of the three major international regions, 2014-2018 (US\$100 million)

\begin{tabular}{lrrrrrrr}
\hline Regions & 2014 & 2015 & 2016 & 2017 & 2018 & $\begin{array}{l}\text { Growth } \\
\text { rate 1 (\%) }\end{array}$ & $\begin{array}{l}\text { Growth } \\
\text { rate 2 (\%) }\end{array}$ \\
\hline Europe, the Middle & 106 & 97 & 96 & 101 & 98 & -3 & -8 \\
$\quad \begin{array}{l}\text { East and Africa } \\
\text { Asia \& Pacific }\end{array}$ & 124 & 142 & 150 & 159 & 167 & 5 & 35 \\
Latin America & 30 & 34 & 28 & 34 & 27 & -21 & -10 \\
Total & 260 & 273 & 274 & 294 & 292 & -1 & 12 \\
\hline
\end{tabular}

Source: Motion Picture Association of America, see (www.mpaa.org/).

Note: Growth rate 1 refers to the growth rate of 2018 relative to 2017, while growth rate 2 refers to the growth rate of 2018 relative to 2014 .

2018 (US\$29.2 billion) decreased a little compared with the box office in 2017, it had increased by 12 percent compared to the box office performance in 2014.

It is seen from the comparison of overall box office among different regions in Table 3.2 that the Asia \& Pacific region achieved the highest increase rate in overall box office in 2018 (US\$16.7 billion), compared with the box office income of the Asia \& Pacific region in 2014 (US\$12.4 billion). The box office of the region in 2018 increased by 5 percent compared to 2017 and 35 percent compared to 2014 , respectively.

It is shown in Table 3.3 that the annual admission numbers of filmgoers in North America in 2018 was 1.3 billion, which was a slight increase compared to 2017 and the average cinema attendance per person was 3.7 times, which also was an increase compared to 2017.

As shown in Table 3.4, the cinema admission numbers in North America were 1.304 billion, which was much higher than the numbers of admission of visitors to theme parks and sports events whose total was 0.552 billion. 
Table 3.3 Comparison of the number of people watching movies in North America and the number of times per capita, 2007-2018 (100 million people)

\begin{tabular}{lccccccccccccc}
\hline Index & 2007 & 2008 & 2009 & 2010 & 2011 & 2012 & 2013 & 2014 & 2015 & 2016 & 2017 & 2018 \\
\hline $\begin{array}{l}\text { The number of } \\
\text { people }\end{array}$ & 14.0 & 13.4 & 14.2 & 13.4 & 12.8 & 13.6 & 13.4 & 12.7 & 13.2 & 13.2 & 12.4 & 13.0 \\
$\begin{array}{c}\text { Average number } \\
\text { of times of } \\
\text { attendance }\end{array}$ & 4.4 & 4.2 & 4.3 & 4.1 & 3.9 & 4.1 & 4.0 & 3.7 & 3.8 & 3.8 & 3.6 & 3.7 \\
\hline
\end{tabular}

Source: Motion Picture Association of America, see (www.mpaa.org/).

Table 3.4 The participation rates of different entertainment activities in North America, 2009-2018 (100 million people)

\begin{tabular}{llll}
\hline Year & $\begin{array}{l}\text { Cinema } \\
\text { attendance }\end{array}$ & $\begin{array}{l}\text { Number of theme } \\
\text { park visitors }\end{array}$ & $\begin{array}{l}\text { The number of people who } \\
\text { watch sports in a stadium }\end{array}$ \\
\hline 2009 & 14.15 & 3.42 & 1.33 \\
2010 & 13.41 & 3.39 & 1.32 \\
2011 & 12.85 & 3.50 & 1.33 \\
2012 & 13.58 & 3.59 & 1.31 \\
2013 & 13.43 & 3.71 & 1.25 \\
2014 & 12.68 & 3.79 & 1.34 \\
2015 & 13.21 & 3.88 & 1.34 \\
2016 & 13.15 & 4.10 & 1.34 \\
2017 & 12.40 & 4.14 & 1.33 \\
2018 & 13.04 & 4.21 & 1.31 \\
\hline
\end{tabular}

Source: Motion Picture Association of America (www.mpaa.org/).

As shown in Tables 3.5 and 3.6, the number of films that have been rated in recent years has been declining. The number of rated films in 2018 was far less than the number of films distributed. In 2018, there were 564 rated films and 758 distributed films, which demonstrated that more unrated art films and documentaries could be seen in cinemas. More independent and low-budget productions have entered the cinema circuit. This is a healthy and ecological trend.

Although the number of films released by the six major film studios has declined year on year in the past 10 years, the total box office revenue is not necessarily lower than before. In 2018, the six major Hollywood companies and their art film brands released a total of 127 films, including those released in 2017 which continue to be released in 2018. Among the top 100 box office films in North America, films released by the six major studios accounted for 78 , with a total box office of US\$9.67 billion, accounting for approximately 81.3 percent of North America's annual box office. This data clearly demonstrate that the film industry and box office still pose great 
Table 3.5 Number of films released in North America, 2007-2018

\begin{tabular}{|c|c|c|c|c|c|c|c|c|c|c|c|c|}
\hline Type & 2007 & 2008 & 2009 & 2010 & 2011 & 2012 & 2013 & 2014 & 2015 & 2016 & 2017 & 2018 \\
\hline $\begin{array}{l}\text { Number of films } \\
\text { released }\end{array}$ & 611 & 638 & 557 & 563 & 609 & 678 & 658 & 706 & 707 & 732 & 785 & 758 \\
\hline $\begin{array}{l}\text { The number of } 3 \mathrm{D} \\
\text { films released }\end{array}$ & 6 & 8 & 18 & 29 & 53 & 56 & 54 & 48 & 39 & 51 & 46 & 42 \\
\hline $\begin{array}{l}\text { The number of large } \\
\text { screens releases, } \\
\text { such as IMAX }\end{array}$ & 11 & 15 & 14 & 16 & 21 & 26 & 32 & 30 & 36 & 42 & 41 & 56 \\
\hline $\begin{array}{l}\text { The number of films } \\
\text { produced by MPAA } \\
\text { member companies }\end{array}$ & 107 & 108 & 111 & 104 & 104 & 94 & 84 & 99 & 100 & 101 & 86 & 92 \\
\hline $\begin{array}{l}\text { The number of films } \\
\text { produced by art films } \\
\text { brands of MPAA } \\
\text { member companies }\end{array}$ & 82 & 60 & 47 & 37 & 37 & 34 & 30 & 36 & 47 & 42 & 44 & 35 \\
\hline $\begin{array}{l}\text { MPAA member } \\
\text { companies' total } \\
\text { number of films }\end{array}$ & 189 & 168 & 158 & 141 & 141 & 128 & 114 & 135 & 147 & 143 & 130 & 127 \\
\hline $\begin{array}{l}\text { The number of films } \\
\text { produced by non- } \\
\text { members of the } \\
\text { MPAA }\end{array}$ & 422 & 470 & 399 & 422 & 468 & 550 & 544 & 571 & 560 & 589 & 655 & 631 \\
\hline
\end{tabular}

Source: Motion Picture Association of America, see (www.mpaa.org/).

Table 3.6 The number of films rated in North America, 2007-2018

\begin{tabular}{lllllllllllllll}
\hline Type & 2007 & 2008 & 2009 & 2010 & 2011 & 2012 & 2013 & 2014 & 2015 & 2016 & 2017 & 2018 \\
\hline $\begin{array}{l}\text { The number of films } \\
\text { produced by }\end{array}$ & 233 & 201 & 177 & 174 & 169 & 166 & 169 & 165 & 167 & 176 & 176 & 166 \\
$\begin{array}{l}\text { MPAA member } \\
\text { companies }\end{array}$ & & & & & & & & & & & & \\
$\begin{array}{l}\text { The number of films } \\
\text { produced by non- } \\
\text { members of the } \\
\begin{array}{l}\text { MPAA } \\
\text { Total }\end{array}\end{array}$ & 607 & 696 & 616 & 532 & 589 & 560 & 544 & 543 & 446 & 429 & 387 & 398 \\
\hline
\end{tabular}

Source: Motion Picture Association of America (www.mpaa.org/).

challenges for independent film production and distribution companies, but in different forms.

\section{Changes in the scale and structure of the US film and television industry}

According to the information provided by the US Department of Commerce in early 2019, the market size of the US Entertainment and Media industry (including film and television entertainment and music, 
broadcasting, publishing, games and other related industries) in 2018 was US\$735 billion, and the trend of this data is continuing to rise. According to PricewaterhouseCoopers, this amount will increase to US\$830.6 billion by 2022 .

According to the MPAA statistics, in 2010, the box office accounted for a small portion (20 percent) of the total revenue of the American film industry, TV revenue (including cable TV, TVB, pay-per-view TV) accounted for 40 percent, home entertainment audio-visual products accounted for 36 percent. In addition, there was 4 percent of ancillary service revenue, including revenue from broadcasting services provided on cruise ships, airplanes, trains and other transportation forms.

In 2018, the box office in North America was US\$11.9 billion, and the total revenue of the home entertainment audio-visual market and digital distribution was US\$23.279 billion. In recent years, with the rapid development of digital technology and the popularity of the Internet with high speed streaming, sales of traditional home entertainment DVD and Blu-ray discs in the United States have declined, but sales of digital home entertainment products have been on the rise. Digital home entertainment products include electronic downloads, video-on-demand (VOD) and streaming subscriptions or annual subscription services. In 2018, the sales and rental output value of traditional home entertainment DVD and Blu-ray discs in North America were US $\$ 4$ billion and US $\$ 1.79$ billion, a decrease of 14.6 percent and 15.6 percent, respectively, compared to the same period in 2017, and a decrease of more than 50 percent compared to 10 years ago. In 2018, the output value of digital media of home entertainment products reached US $\$ 17.46$ billion, an increase of 24.3 percent compared to the same period in 2017 (see Table 3.7).

The rapid development of digital technology has brought great challenges to traditional media forms and has had a negative impact on the movie box office, yet digital technology is actually an indispensable aspect in the development of the film industry. Most of the successful movies today use advanced movie technology, and many new technologies appear in movies every year. Films such as Avatar, Jurassic World, Avengers: Infinity War applied many new digital technologies. Some films waited many years before shooting, because it is necessary to wait until the technology has been developed and matured, new visual effects thus can be made. Alita: Battle Angel is an example.

\section{Comparison of the development of the six major film and television groups in Hollywood}

The six major Hollywood companies are media groups with immense economic and commercial strength. Each of these six companies has its own unique running and operating model. Meanwhile, they also have very similar company frameworks and structures, focusing on using existing resources, developing potentials, reintegrating resources, and making full use of synergies to enable companies to achieve the highest efficiency and maximize 
Table 3.7 Total home entertainment expenditures for movies in the United States, 2010-2018 (million US\$)

\begin{tabular}{|c|c|c|c|c|c|c|c|c|c|c|}
\hline Type & & 2010 & 2011 & 2012 & 2013 & 2014 & 2015 & 2016 & 2017 & 2018 \\
\hline \multirow[t]{2}{*}{ Sales } & $\begin{array}{l}\text { DVD and Blu-ray disc } \\
\text { sales }\end{array}$ & 10321.07 & 8951.8 & 8462.18 & 7779.19 & 6934.81 & 6070.17 & 5490.57 & 4716.37 & 4029.87 \\
\hline & $\begin{array}{l}\text { Total sales (including } \\
\text { streaming sales) }\end{array}$ & 10829.15 & 9554.65 & 9270.6 & 8968.5 & 8535.79 & 7976.8 & 7527.34 & 6870.1 & 6494.47 \\
\hline \multirow[t]{5}{*}{ Rent } & Rent & 2309.32 & 1599.21 & 1216.02 & 955.59 & 692.59 & 616.27 & 488.05 & 388.97 & 317.08 \\
\hline & $\begin{array}{l}\text { Monthly subscription } \\
\text { (DVD and Blu-ray } \\
\text { only) }\end{array}$ & 2272.14 & 1741.22 & 1258.09 & 1015.06 & 793.11 & 658.87 & 547.57 & 454.87 & 364.15 \\
\hline & $\begin{array}{l}\text { Self-operated rental } \\
\text { machines near } \\
\text { supermarkets and } \\
\text { convenience stores }\end{array}$ & 1269.1 & 1676.46 & 1937.77 & 1895.1 & 1836.81 & 1732.24 & 1514.87 & 1271.79 & 1104.62 \\
\hline & $\begin{array}{l}\text { Total rental for DVD } \\
\text { and Blu-ray }\end{array}$ & 5850.56 & 5016.88 & 4411.89 & 3865.75 & 3322.51 & 3007.39 & 2550.49 & 2115.63 & 1785.85 \\
\hline & $\begin{array}{l}\text { Including the total rent } \\
\text { of streaming media } \\
\text { rental }\end{array}$ & 7602.22 & 6801.31 & 6424.19 & 5974.47 & 5303.9 & 4975.86 & 4655.55 & 4080.86 & 3872.84 \\
\hline \multirow{4}{*}{$\begin{array}{l}\text { Digital } \\
\text { distribution }\end{array}$} & Streaming media sales & 508.08 & 602.85 & 808.42 & 1189.31 & 1600.98 & 1906.62 & 2036.77 & 2153.72 & 2464.61 \\
\hline & $\begin{array}{l}\text { Single paid streaming } \\
\text { video on demand }\end{array}$ & 1751.66 & 1784.43 & 2012.3 & 2108.72 & 1981.39 & 1968.47 & 2105.06 & 1965.23 & 2086.99 \\
\hline & $\begin{array}{l}\text { Paid monthly streaming } \\
\text { video on demand }\end{array}$ & - & 1603.14 & 2394.73 & 3190.74 & 4066.29 & 5081.88 & 7286.7 & 9926.62 & 12911.9 \\
\hline & $\begin{array}{l}\text { Total sales of streaming } \\
\text { media and video on } \\
\text { demand }\end{array}$ & 2259.74 & 3990.42 & 5215.45 & 6488.77 & 7648.66 & 8956.97 & 11428.53 & 14045.6 & 17463.5 \\
\hline \multicolumn{2}{|c|}{$\begin{array}{l}\text { Total spending on home entertainment in } \\
\text { the United States }\end{array}$} & 18431.38 & 17959.1 & 18089.52 & 18133.71 & 17905.98 & 18034.53 & 19469.59 & 20877.6 & 23279.2 \\
\hline
\end{tabular}

Note: The discrepancy between the total and the sum of each item is caused by rounding.

Source: Digital Entertainment Group, see (www.degonline.org/. 
Table 3.8 The turnover of the six major Hollywood film and television companies and their parent companies in the fiscal years 2015-2018 (million US\$)

\begin{tabular}{|c|c|c|c|c|c|c|c|c|}
\hline \multirow[t]{2}{*}{ Company } & \multicolumn{4}{|c|}{ Revenues } & \multicolumn{4}{|c|}{ Operating income } \\
\hline & 2015 & 2016 & 2017 & 2018 & 2015 & 2016 & 2017 & 2018 \\
\hline $\begin{array}{l}\text { Comcast } \\
\text { Corporation }\end{array}$ & 74510 & 80736 & 85029 & 94507 & 15998 & 16831 & 18018 & 19009 \\
\hline $\begin{array}{l}\text { NBC Universal } \\
\text { Corporation }\end{array}$ & 28462 & 31276 & 32836 & 35761 & 4819 & 5333 & 6177 & 6490 \\
\hline $\begin{array}{l}\text { NBC Universal } \\
\text { Pictures } \\
\text { Entertainment }\end{array}$ & 7287 & 6229 & 7595 & 7152 & 1208 & 615 & 1167 & 589 \\
\hline $\begin{array}{l}\text { The Walt Disney } \\
\text { Company }\end{array}$ & 52465 & 55632 & 55137 & 59434 & 14681 & 15721 & 14775 & 15706 \\
\hline $\begin{array}{l}\text { Walt Disney Pictures } \\
\text { Corporation }\end{array}$ & 7366 & 9441 & 8379 & 9987 & 1973 & 2703 & 2355 & 2980 \\
\hline AT\&T Company & 146801 & 163783 & 160546 & 170756 & 20362 & 23543 & 19970 & 26096 \\
\hline $\begin{array}{l}\text { Time Warner } \\
\text { Group/Warner } \\
\text { Media Group }\end{array}$ & 28118 & 29318 & 31271 & 18941 & 6865 & 7547 & 7920 & 5670 \\
\hline $\begin{array}{l}\text { Warner Bros. } \\
\text { Entertainment }\end{array}$ & 12992 & 13037 & 13866 & 8703 & 1416 & 1734 & 1761 & 1477 \\
\hline 21st Century Fox & 28987 & 27326 & 28500 & 30400 & 6722 & 6597 & 7173 & 7032 \\
\hline $\begin{array}{l}\text { 20th Century Fox } \\
\text { Film } \\
\text { Corporation }\end{array}$ & 9525 & 8505 & 8235 & 8747 & 1445 & 1085 & 1051 & 962 \\
\hline Viacom Company & 13268 & 12488 & 13263 & 12943 & 3112 & 2526 & 2489 & 2750 \\
\hline $\begin{array}{l}\text { Paramount } \\
\text { Pictures, Inc. }\end{array}$ & 2883 & 2662 & 3289 & 3041 & 111 & -445 & -280 & -39 \\
\hline Sony Corporation & 68582 & 72172 & 68259 & 80592 & 572 & 2620 & 2592 & 6594 \\
\hline $\begin{array}{l}\text { Sony Pictures } \\
\text { Entertainment }\end{array}$ & 7335 & 8353 & 8107 & 9357 & 488 & 343 & -723 & 388 \\
\hline
\end{tabular}

Note: the financial years of each company were as follows: SONY Corporation ended March 31, Fox Corporation ended June 30, Walt Disney Company and Paramount Corporation ended September 30, and AT\&T and Comcast Corporation ended December 31.

profits. Table 3.8 shows the annual turnovers of the six major Hollywood companies and their parent companies in the 2015-2018 fiscal years. The data is taken from the $10-\mathrm{K}^{1}$ statements of each company. The parent company of SONY Pictures Entertainment is SONY Japan, so the company's annual report in the United States was 20-F.

The operating profits of NBC Universal Group and NBC Universal Entertainment were calculated from adjusted EBITDA (earnings before interest, taxes, depreciation and amortization) data, which are used for reference only.

AT\&T, one of the largest telecommunications companies in the United States, became the parent company of Warner Media and Warner Bros. 
Entertainment in 2018. The structure of Warner Media Group is similar to that of Time Warner Group before the merger with AT\&T. The figures in Table 3.8 for fiscal year 2015, fiscal year 2016 and fiscal year 2017 are the financial statements of the Time Warner Group, and fiscal year 2018 is the financial statements of the Warner Media Group. AT\&T's fiscal year 2015, 2016 and 2017 results are for reference only, and the company was not associated with the big six in Hollywood at the time.

Companies calculate their profits in different ways, Table 3.8 lists the operating profit data for reference only. The top parent company of SONY Pictures Entertainment is Japan's SONY Corporation. The monetary unit of 20-F statements is the yen for SONY. This report, according to the state foreign exchange, announced the currency conversion rate against the dollar monthly, and the corresponding exchange rate is respectively: 1 yen $=\$ 0.00835$ $($ March 31, 2015),$=\$ 0.00890($ March 31, 2016) $=\$ 0.00895($ March 31, 2017) and $=\$ 0.0094($ March 31,2018$)$.

As mentioned earlier, the six major Hollywood companies are film and television groups with multiple products. Tables 3.8 and 3.9 provide a clearer look at the position of the film division in the companies. Whether running income or revenue, the film division is not the most profitable one of a company. But film is precisely the key product for branding, which is extremely important to the company. Of the six major companies, with the exception of the Sony Corporation, the parent companies of the five companies own mainstream radio and television media groups in the United States. Over the past two or three decades, radio and television media groups have often been the most profitable and relatively stable parts of these film and television giants. So, despite the high risk of film investment, every major company seems to be able to afford it. In the past 10 years, with the emergence and development of streaming media, TV advertising revenue and PAY-TV audiences have been smaller than before, and the profits of broadcast television media have declined. The investment budgets of Hollywood blockbusters become higher and higher, shooting a blockbuster with an investment of US\$150 million or more is not rare, and then investing the same size budget for global marketing and distribution. If the box office of this movie is not ideal, the company's affordability is tested. The gaps between the six major companies have also become greater in recent years. From Table 3.8 it is not difficult to find the differences between the companies.

\section{The new status of the streaming media and the progress of Netflix in 2018}

\section{Netflix and the streaming media business}

2018 was an important year for Netflix and the streaming media business to challenge traditional Hollywood companies, and 2019 was a new starting point for Netflix to become a mainstream media company in Hollywood. In January 
Table 3.9 Turnover of Walt Disney Company in fiscal years 2015-2018 (million US\$)

\begin{tabular}{|c|c|c|c|c|c|c|c|c|}
\hline \multirow[t]{2}{*}{ Company } & \multicolumn{4}{|c|}{ Revenue } & \multicolumn{4}{|c|}{ Operating income } \\
\hline & 2015 & 2016 & 2017 & 2018 & 2015 & 2016 & 2017 & 2018 \\
\hline $\begin{array}{l}\text { Radio and television } \\
\text { media group }\end{array}$ & 23264 & 23689 & 23510 & 24500 & 7793 & 7755 & 6902 & 6625 \\
\hline $\begin{array}{l}\text { Theme parks and } \\
\text { resorts }\end{array}$ & 16162 & 16974 & 18415 & 20296 & 3031 & 3298 & 3774 & 4469 \\
\hline $\begin{array}{l}\text { Film and television } \\
\text { entertainment } \\
\text { group }\end{array}$ & 7366 & 9441 & 8379 & 9987 & 1973 & 2703 & 2355 & 2980 \\
\hline $\begin{array}{l}\text { Consumer products } \\
\text { and interactive } \\
\text { media division }\end{array}$ & 5673 & 5528 & 4833 & 4651 & 1884 & 1965 & 1744 & 1632 \\
\hline Total & 52465 & 55632 & 55137 & 59434 & 14681 & 15721 & 14775 & 15706 \\
\hline
\end{tabular}

2019, Netflix joined the Motion Picture Association of America (MPAA), becoming one of the seven major Hollywood companies. Compared to the traditional six major Hollywood companies with nearly a century of film production and distribution history, Netflix is a home entertainment industry service company that started out as a DVD rental business. Headquartered in Los Gatos, California, the company was established in 1997, with a history of 20 years. In the first five years after its establishment, the company grew cautiously and followed innovative operating thinking and methods. In 1999, it launched a model that users only pay a dozen dollars a month to watch an unlimited number of DVDs at home, then in 2000 it began to change monthly subscription products to the unlimited time DVD rental model. The fast and cheap DVD rental service provided by Netflix quickly won the favor of many customers. Netflix had also developed from small beginnings to a significant size in a short time. In 2003, it realized an operating profit of US\$4.5 million for the first time, and a total revenue of US\$270 million, of which the net income was US\$6.5 million; in 2004, the number of users increased to 2.61 million people, with an annual turnover of up to US\$500 million, with a net income of US\$22 million; in 2005, the number of users increased to 4.18 million, with an annual turnover of up to US\$680 million, with a net income of US\$42 million; in 2006, it had 6.32 million users, with an annual turnover of US\$997 million, with a net income of US\$49 million. At the 10th anniversary of the company in 2007, Netflix's performance was even better: the number of users increased to 7.48 million, the annual turnover reached US $\$ 1.2$ billion, and the net income was US\$67 million. Netflix's 2016 $10-\mathrm{K}$ statement showed that Netflix's turnover was US $\$ 8.83$ billion and its operating profit was US\$379 million. Netflix's 2017 10-K statement showed that Netflix's turnover was US\$11.693 billion and its operating profit was 
US\$839 million. The financial report released by Netflix in early 2019 shows that Netflix's 2018 turnover was US\$15.794 billion and its operating profit was US\$1.605 billion.

Netflix, while focusing on marketing, has always paid attention to the number of licensed films in its own film library. In 2005, Netflix's library had 35,000 movies for users to choose from, and the number of DVDs rented daily was as high as one million. With the development of digital technology, bandwidth widening and speeding up of the Internet, in 2007, Netflix launched a monthly video-on-demand service for streaming media. In 2008, the number of clicks on Netflix's website reached 194 million, which was five times the number of visitors to BesTV, the largest film and audio chain store in North America in early 2000. In less than 10 years since Netflix's emergence, its service and operating model has caused many movie and television rental stores in the United States to close or change their operations.

Since 2010, Netflix's streaming media content on-demand service business has expanded overseas: the first stop was Canada, the second was Latin American countries. In 2012, Netflix began to expand its streaming media business in Europe. Up to the beginning of 2016, Netflix's global streaming businesses had expanded to more than 190 countries and regions, with a total of 74 million users. In April 2017, Netflix and the well-known Chinese video site iQiyi signed a license distribution contract, users can see many original videos and TV series owned by Netflix on the iQiyi website. At the end of 2018, the total number of customers of Netflix's global streaming media business reached 148 million (see Table 3.10).

Since 2011, in addition to obtaining authorized film and television programs from traditional Hollywood companies through copyright transactions, Netflix has also entered the field of original production of film and television programs. At that time, Netflix had less than 27 million users. House of Cards and Orange Is the New Black were among Netflix's first productions. Netflix directly challenged traditional film and television companies, including the

Table 3.10 Number of Netflix members, 2015-2018 (in 10,000s)

\begin{tabular}{llcccc}
\hline Type & & 2015 & 2016 & 2017 & 2018 \\
\hline Domestic streaming & All members & 4473.8 & 4943.1 & 5475 & 6055.1 \\
$\quad$ media & Paying members & 4340.1 & 4790.5 & 5281 & 5848.6 \\
International streaming & All members & 3002.4 & 4436.5 & 6283.2 & 8790.4 \\
$\quad$ media & Paying members & 2743.8 & 4118.5 & 5783.4 & 8077.3 \\
All streaming media & All members & 7476.2 & 9379.6 & 11758.2 & 14845.5 \\
& Paying members & 7083.9 & 8909 & 11064.4 & 13925.9 \\
Domestic DVD and & All members & 490.4 & 411.4 & 338.3 & 273.1 \\
Blu-ray disc & Paying members & 478.7 & 402.9 & 333 & 270.6 \\
\hline
\end{tabular}

Source: Netflix. 
six major Hollywood companies. Netflix has a huge number of paying users and a relatively stable annual income, its purchase budget challenges art film brands belonging to the six major companies.

In recent years, Netflix has directly competed with the six major Hollywood companies by hiring top managers. Shonda Rhimes, an experienced producer of TV series such as Grey's Anatomy, Scandal, and How to Get Away with Murder, signed with Netflix in 2017. Later, in December 2018, Netflix signed the former president and producer of the Disney Company's ABC Entertainment, Channing Dungey, hiring him as Vice President of the company's original shows since February 2019.

In 2018, Netflix invested nearly US\$13 billion in original film and television productions and copyright procurement, of which 85 percent of the budget was for original production. In 2018, Netflix released 82 new feature films over 90 minutes in streaming format, which was far more than any of the six major Hollywood companies. In December 2018, Netflix launched the thriller science fiction film Bird Box, starring American actress Sandra Bullock, which was first released at the American Film Institute Film Festival in November 2018 and launched in December on streaming platforms in dozens of countries around the world, including the United States. According to Netflix's report, the number of moviegoers in the first week of the film reached 45 million, and the total number of moviegoers worldwide reached 80 million in four weeks. By the end of 2018, there were almost 1,000 original TV series owned by Netflix's streaming platform. 2018 was also an important year for Netflix to innovate in producing original content and media expressions. Netflix launched its first video gamelike feature film, Black Mirror: Bandersnatch on its own streaming platform on December 28. This was not only Netflix's innovation in streaming media business but also in feature film innovation in the form of audience viewing experience. Movie viewers are no longer just "viewers", which means just watching on the screen with their eyes, but become "personal experiencers", using their own imagination and expectations to influence the plots and ending of the film. Although this form of media expression is still in its infancy, and audiences have limited choices, this is at least a starting point for a new film viewing experience innovation. This innovator, however, is a latecomer who started with DVD rental and a streaming media business only 20 years ago, rather than other traditional film and television companies in Hollywood, who have a history of decades or even a hundred years.

On January 6, 2019, at the 76th Golden Globe Awards in Los Angeles, California, Netflix's original film and television works won a total of five Golden Globes (20 percent of all awards), becoming the big winner at the Golden Globes. The award-winning film Roma, a black-and-white movie, directed by Mexican film director Alfonso Cuarón, starring Aliza Abaricio and Marina de Tavira, was premiered at the 75th Venice International Film Festival in Italy on August 30, 2018, and was later screened at the Telluride 
Film Festival in northern California on August 31, 2018. In the following months, it won dozens of awards and nominations at many international film festivals. Director Alfonso Cuarón won the 76th Golden Globe Award for Best Director for the film. In January 2019, Roma won the best film nomination in the 91st Academy Awards, and director Alfonso Cuarón also won the Best Director nomination.

Netflix also launched the film The Irishman in 2019, which was directed by Martin Scorsese, starring Robert De Niro and Al Pacino. The cost of the film reached hundreds of millions of dollars, a Hollywood blockbuster. In January 2019, Netflix raised the price of membership fees in the United States, increasing the monthly basic membership fee from US\$7.99 to US\$8.99, and increasing the monthly membership fee of standard-level from US\$10.99 to US\$12.99. Monthly advanced membership fees increased from US\$13.99 to US\$15.99. This substantial increase in membership fees was closely related to the increase in the number of members and the significant improvements in business performance of Netflix in 2018. It was also an important step in the development of Netflix's corporate strategy. In February 2019, Netflix also signed an authorization contract for the overseas distribution of The Wandering Earth.

\section{Mainstream Hollywood companies gradually launch streaming services}

Among the six major Hollywood companies, Disney, Universal Pictures, and Warner Bros. have accelerated the pace of providing streaming services. In 2019, Disney launched the Disney + streaming business. AT\&T and its Warner Media Group also launched a streaming media service similar to Walt Disney's which is direct-to-consumers. Universal Television and its parent company Comcast will also join the group of film and television companies that provide streaming media services in 2020 .

\section{Walt Disney Direct-to-Consumer \& International}

The following are Disney's new developments in 2018. In May 2018, the Walt Disney Company established a new operating group subsidiary, with streaming media service as the main body, including the company's international business and home entertainment business, and even $\mathrm{ABC}$, one of the three major American television networks, which was also owned by this new company. The new company is called "Walt Disney Direct-to-Consumer \& International." The Walt Disney Direct-to-Consumer \& International is a subsidiary of the Walt Disney Company. There also is a new major business unit that includes Disney Streaming Services (Disney + and ESPN +), Overseas Media Business, and ESPN Global Advertising Sales, The domestic television network ABC, the worldwide Disney Channel and other television channels' advertising, licensing and sales operations, etc., BAMTech Technologies also belong to the new company. 
The Walt Disney Direct-to-Consumer \& International is an important strategic step for the Walt Disney Company. The Company promoted Kevin Mayer, an experienced employee of the Walt Disney Company, who had been with the company since 1993, to be the executive of the new company. He reports directly to Walt Disney CEO Robert Iger. Kevin Mayer holds a bachelor's and master's degree in engineering as well as a master's degree in business administration from Harvard University. During his long career, he had participated in the acquisition of Pixar Animation, Marvel, Lucas and 20th Century Fox Pictures by the Walt Disney Company. It is predicted that Kevin Mayer might be the successor to Robert Iger.

In 2018, before film and television, the Walt Disney Direct-to-Consumer \& International Corporation successfully launched sports media channel streaming products and service, which was named ESPN +. At the end of December 2018, Disney Corporation and the American telecommunications company Verizon reached a cooperation agreement. Together, they would continue to provide ESPN sports program services for Verizon's existing sports audience.

In 2018, the Walt Disney Company and the Internet giant Google also reached a cooperation agreement. The two parties would cooperate in the advertising business. This cooperation had been negotiated for a year. According to media information company ComScore, in September 2018, Disney's digital product content owned 23 million users worldwide, these users would spend 14 billion minutes watching Disney shows every month.

The Walt Disney Company completed the purchase of 20th Century Fox Films, one of the six major Hollywood companies, on March 19, 2019. In 2019, Walt Disney Direct-to-Consumer \& International launched Disney streaming products and services Disney + . This product not only includes all the familiar Disney products, such as the Disney brand, the Pixar brand, the Marvel brand, the Lucas brand and the Star Wars brand, etc., but also includes 20th Century Fox, Fox Searchlight Pictures and other brands' products. In addition, Disney no longer continues to authorize other online channels before the term of the product content mentioned above has expired.

Comcast, the parent company of Universal Pictures Group, also merged with the Sky Broadcasting Media Group (Sky) (which used to be a subsidiary of 21st Century Fox and covered Europe's major radio and television telecommunications and mobile phone user groups) in 2018. The Walt Disney and Comcast companies' annual content production budgets reached nearly US $\$ 43$ billion, accounting for approximately 20 percent of the global film and television entertainment media content production budget.

The operating performances of traditional Hollywood companies and new streaming companies in 2018 indicated that these content channels of different consumption forms and different platforms will continue to coexist. As consumers continue to change their consumption habits, content and 
platform providers will also introduce new content and consumption forms that are more suitable to consumer habits and preferences.

\section{Warner Media Group}

In 2018 and early 2019, another major event in Hollywood was the change of the parent company of Warner Group. Warner Television Group and its sister companies, HBO Cable Broadcasting Corporation and Turner Broadcast, were taken over by AT\&T, the largest telecommunications company in the United States, becoming its wholly owned subsidiary, named Warner Media. In 2019, Warner Media Group also launched a streaming service similar to Walt Disney's Direct-to-Consumer \& International company.

Digital media production and distribution companies that have challenged traditional Hollywood media companies include Amazon Pictures, a subsidiary of Amazon Group, and YouTube. Not only do they compete with Netflix, but they also challenge traditional film and television production and distribution companies.

\section{Development trends and future prospects of the North American film industry}

\section{Mergers and acquisitions of the North American film and entertainment industry groups will continue}

The six major Hollywood companies developed into seven companies (with the addition of Netflix) in early 2019, but soon reverted to six major companies. This was the biggest event in Hollywood in 2018 and 2019. The Walt Disney Company completed the acquisition of 20th Century Fox, one of the six major Hollywood companies in March 2019 after acquiring Pixar, Marvel and Lucas. 20th Century Fox used to be not only a group company with a complete film and television industry chain, but also a company with a higher operating profit among the six major Hollywood companies, and once owned many Oscar-winning films and Fox Searchlight brands.

Six years after Comcast, the top parent company of Universal Pictures, acquired NBC Universal Pictures Entertainment, Comcast's ranking among the top 500 U.S. companies rose from 66th in 2011 to 33rd in 2018 and even 31 st in 2017. In 2018, when Comcast acquired most of the assets of 20th Century Fox from the Walt Disney Company, it also acquired Star Broadcast Media Group in Europe, which used to belong to 21st Century Fox.

In 2018, AT\&T, the largest telecommunications company in the United States, acquired Time Warner, becoming the parent company of Warner Media, and launched a streaming service similar to that of Walt Disney Direct-to-Consumer \& International. The merger and acquisition made full use of the customer base, hardware services such as corporate 
telecommunications and networking, and a large number of databases and creative resources of several companies before the merger to create an updated business model.

\section{Sino-US film and television cooperation programs have made great progress}

In 2018, the China-US co-production The Meg laid the foundation for the co-production in the market. The film, which cost about US\$130 million to produce and distribute, premiered simultaneously in 15 countries, including China, the United States, and the United Kingdom on August 10, 2018. In August, the film was released in more than 40 countries around the world. The global box office reached US\$530 million, of which China's box office was US\$153 million and the US box office was US $\$ 145$ million. The box office revenue of such an international film was only about 30 percent of the copyright revenue, and 70 percent of the copyright revenue came from the television licensing, DVD and Blu-ray disc markets, streaming media licensing, and aircraft and cruise ship licensing.

Of course, Kung Fu Panda 3, a Sino-US co-production by the Oriental Dream Works and China Film Company in 2016 must not be forgotten. Kung Fu Panda and Kung Fu Panda 2 are both American films, and Kung Fu Panda 3, the large-scale 3D blockbuster was partly funded and produced by Chinese teams. Kung Fu Panda 3 is really two original versions: an English original animation and a Chinese original animation. The production of this movie was difficult, the use of resources and the production period were extremely challenging. The film has a global box office of US\$521 million, of which China's box office was US\$154 million, and the US box office was US\$143 million.

These two Sino-US co-productions have opened a new way to Sino-US film co-operation, which is valuable and worth learning. The hope is that in future there will be more exciting co-productions.

\section{Future prospects for the new and the old companies}

The impact of streaming media and the Internet on the traditional Hollywood model will inspire more new works, new forms and new stages that are welcomed by audiences. Traditional Hollywood film production and distribution companies are also constantly updating their operating models. A 2018 report from a media market research company showed that Internet companies, including Netflix, have not prevented loyal moviegoers from going to the cinema, but the moviegoers are mostly mainstream streaming audience who also stream on the Internet and spend more time watching movies.

Creating, innovating and setting new business models will continue to be one of the main tasks guaranteeing the enduring development of the American and global film and television industries. 


\section{Note}

1 The $10-\mathrm{K}$ statement is a statement required by the US Securities and Exchange Commission to be completed by all listed companies and filed with the US Securities and Exchange Commission within 90 days of the year-end settlement date. The 10$\mathrm{K}$ statement is also a summary report that reports to the company's shareholders on the company's history, organizational structure, stock rights, subsidiaries, and audited annual financial statements at the end of the year. 